\title{
Multi-cohort stand structure as a coarse filter of variation in mixedwood boreal bird communities
}

\author{
by Mike V.A. Burrell ${ }^{1,2}$, Jay R. Malcolm¹,* and Pierre Drapeau ${ }^{3}$
}

\begin{abstract}
In targeting mature and over-mature forests for harvesting, management in the boreal forest has resulted in a net loss of older forests that often exhibit complex structural variation and multiple cohorts of trees. Multi-cohort forest management has been proposed as a management approach for these older forests that maintains structural wildlife habitat attributes. At the stand level, the approach relies on various partial harvest techniques to emulate the range of structural variation found in natural boreal landscapes. Here, we examine the extent to which boreal bird communities respond to multi-cohort-related structural variation in boreal mixedwood forests. In particular, we test the utility of parameters of Weibull distributions fitted to stand stem diameter distributions, which have figured prominently in methods to characterize multi-cohort structure, to explain variation in the entire bird community and in various species groupings defined by feeding guilds and forest-type associations. We also compare the explanatory power of the two Weibull parameters against 21 forest structure variables and stand age. In general, Weibull parameters outperformed stand age as a correlate of bird community variation and they were significant explanatory variables for the matrix of all species and for four species groupings, whereas age was significant for only one species grouping. When one or the other Weibull parameter was significant, it also tended to be significant even when variation due to the other was partialled out, supporting the importance not only of forest stature, but also of forest heterogeneity in understanding bird community composition. Thus, we found that multi-cohort-associated structural variation was important in explaining variation among boreal bird communities, supporting the idea of silvicultural approaches that aim at diversifying stand structural characteristics.
\end{abstract}

Keywords: bird habitat, forest resource inventory, canopy structure, boreal mixedwood forest, multi-cohort management, Weibull, stem diameter distribution

\section{RÉSUMÉ}

En axant la récolte sur les forêts mûres et surannées, laménagement de la forêt boréale a entraîné une perte nette de forêts anciennes qui présentent souvent des variations structurales complexes et une multitude de cohortes d'arbres. Il a été proposé d'utiliser l'aménagement forestier multi-cohortes pour aménager ces vieilles forêts afin de maintenir les attributs structuraux de l'habitat faunique. À léchelle du peuplement, lapproche repose sur différentes techniques de coupe partielle pour imiter toute la variété de structures qui se retrouve dans les paysages boréaux naturels. Dans cet article, nous examinons dans quelle mesure les communautés d’oiseaux boréaux répondre aux variations de structure liées à lapproche multi-cohorte dans les forêts boréales mixtes. De façon plus particulière, nous vérifions l'utilité des paramètres de distributions de Weibull adaptées aux distributions de diamètres dans les peuplements, qui se distingue parmi les méthodes pour caractériser la structure multi-cohorte, afin dexpliquer la variation dans toute la communauté doiseaux et dans divers groupes despèces définis par les associations guildes alimentaires et types forestiers. Nous comparons également le pouvoir explicatif des deux paramètres de Weibull pour 21 variables de structure forestière et lầge du peuplement. En général, les paramètres de Weibull sont mieux corrélés que lâge du peuplement avec la variation des communautés doiseaux et constituent des variables explicatives importantes de la matrice de toutes les espèces et pour quatre groupes d’espèces donnés, alors que lâge ne létait que pour un seul groupe despèces. Lorsque l'un ou lautre des paramètres de Weibull savérait significatif, il tendait aussi à le demeurer même lorsquon éliminait la variation due à lautre, ce qui confirme l'importance non seulement de la stature de la forêt, mais aussi de son hétérogénéité pour comprendre la composition des communautés aviaires. Ainsi, nous avons constaté que la variation structurale associée à laménagement multi-cohortes expliquait une grande partie de la variation au sein des communautés doiseaux boréaux, renforçant lidée d'utiliser des approches sylvicoles visant à diversifier les caractéristiques structurales des peuplements.

Mots-clés : habitat des oiseaux, inventaire des ressources forestières, structure du couvert, forêt boréale mixte, aménagement multi-cohortes, Weibull, la distribution des diamètres de tiges

\footnotetext{
${ }^{1}$ Faculty of Forestry, 33 Willcocks St., University of Toronto, Toronto, Ontario M5S 3B3.

${ }^{2}$ Present address: 167 Bird Road, R.R. 5 Quinte West, Ontario K0K 3E0. E-mail: mike.burrell.on@gmail.com.

${ }^{3}$ Centre détude de la forêt (CEF), UQAT-UQAM NSERC Industrial Chair in Sustainable Forest Management, Département des Sciences Biologiques, Université du Québec à Montréal, C. P. 8888, Succursale Centre-Ville, Montréal, Québec H3C 3P8.

*Corresponding author. E-mail: jay.malcolm@utoronto.ca
} 


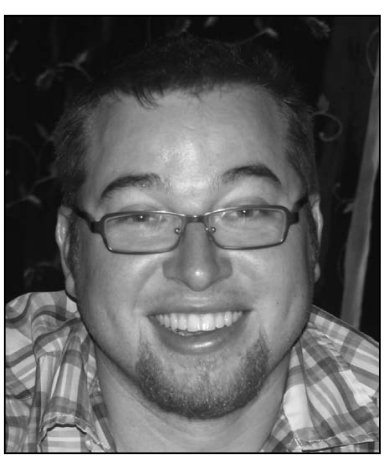

Mike V.A. Burrell

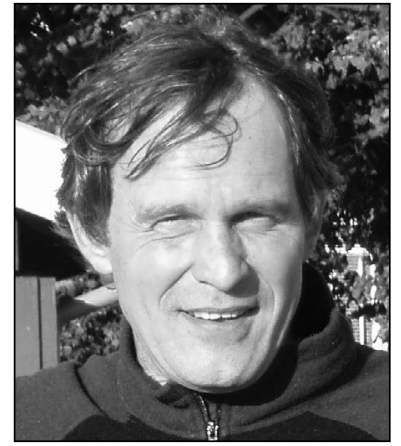

Jay R. Malcolm

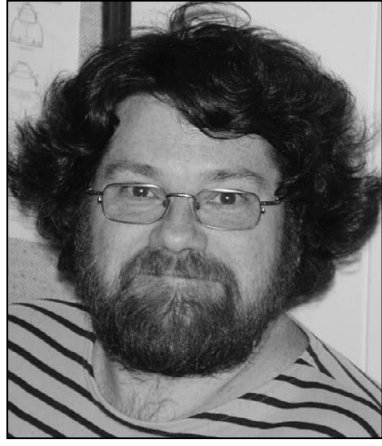

Pierre Drapeau

(Bergeron and Harvey 1997, Bergeron et al. 2002). For example, Bergeron et al. (1999) and Harvey et al. (2002) defined various developmental stages or "cohorts," from even-aged, "single cohort" stands to multi-aged "multicohort" stands that could be managed using different silvicultural techniques.

Development of MCM as a forest management approach requires an understanding of natural stand dynamics and of the variability of forest structure

\section{Introduction}

Since the early 1990s, coarse-filter strategies have been recognized as a cornerstone in conserving biological diversity (e.g., Franklin 1993). A natural disturbance-based coarse-filter approach (Attiwill 1994) is now an underlying premise of forest management in Ontario (OMNR 2001). Although insect damage affects more area annually in the boreal forest, fire is the most important form of primary natural disturbance in boreal forests; for example, Amiro et al. (2001) estimated that fires consume about three million hectares of forests per year in Canada alone. Because of this, forestry in the boreal forest has relied largely on even-aged management and clearcut silviculture as a surrogate for stand-replacing disturbances, according to the rationale that they should ensure both timber production and biodiversity conservation (OMNR 2001).

However, even-aged management differs from fire regimes in several key respects. For instance, compared to post-harvest stands, post-fire stands often have more retained live trees and many more snags (McRae et al. 2001, Drapeau et al. 2002). From a landscape perspective, even-aged management with relatively short rotations (80-100 years) truncates the age distribution of stands (Bergeron et al. 1999, 2002) and is thus likely to affect organisms that use attributes of older forests such as dead and decaying wood (Drapeau et al. 2009). This last difference may be amplified in regions where the fire cycle is much longer than the rotation age. Recent work suggests, for example, that eastern boreal forests of North America have a much longer average fire-return interval than typical rotation periods of 80 to 100 years (Bergeron et al. 2001, 2004; Gauthier et al. 2002). Moreover, paleoecological studies indicate that long fire cycles have persisted throughout much of the Holocene postglacial period (Carcaillet et al. 2001, Cyr et al. 2009). Given the relatively short life span of many boreal tree species, such long fire-return intervals result in a large proportion of the landscape that is composed of relatively old stands with multiple cohorts of trees (Kneeshaw and Bergeron 1996, Bergeron et al. 1995). Gauthier et al. (2002) found that almost half of the Lake Abitibi Model Forest in northeastern Ontario was composed of such old, multi-cohort stands.

The net result of current even-aged management is that it only partly emulates the natural disturbance regime, and hence may not be an effective coarse-filter approach for maintaining biodiversity. A possible alternative management scheme, known as multi-cohort management (MCM), proposes various silvicultural approaches in order to better emulate differing severities of disturbance and to maintain structural complexity within and among stands, especially in the context of biodiversity maintenance. Of particular interest is the importance of multi-cohort stand structures for biodiversity as a whole. In Old World boreal forests, especially in Fennoscandia, structural simplification of boreal forests through long-term, even-aged management coupled with intensive stand tending regimes has been implicated in the decline of a wide range of taxa associated with old growth and over-mature stands (Helle and Jarvinen 1986, Ecke et al. 2002, Edman et al. 2004). In this paper we examine relationships between multi-cohort stand structures and breeding bird communities in boreal forests of northeastern Ontario. Our specific objective is to examine the ability of a key descriptor of a stand's multi-cohort structure (its diameter distribution) to explain bird community variation in comparison to other important stand features, such as forest age and other measurements of habitat structure.

\section{Methods \\ Site selection}

Study sites were in the Romeo-Malette Forest Management Unit in the vicinity of the city of Timmins, Ontario, within Rowe's (1972) Missinaibi-Cabonga Forest Section (Appendix 1). The area is characterized by exposed Canadian Shield in the south, gradually giving way to glacial deposits in the north. The forest management unit is characterized by high abundances of white birch (Betula papyrifera Marsh.), jack pine (Pinus banksiana Lamb.), poplars (Populus spp.), black spruce (Picea mariana [Mill.] BSP), and white spruce (Picea glauca [Moench] Voss) (Remmel et al. 2008).

Forty-five mixedwood sites were selected for study in early May, 2007, based on several criteria. In particular, they were mixedwood, closed-canopy forests that encompassed a variety of age and structure classes and all fell into either the MW2 (mixedwoods with an abundant hardwood component) or the SF1 (mixedwoods with a greater softwood component) "standard forest unit" as identified in the Forest Resource Inventory (FRI; Ontario Ministry of Natural Resources [OMNR], unpubl.). Based on field measurements, sites had 5\% to $79 \%$ deciduous basal area (mean $=42 \%$ ) and the most abundant tree species (by percent of all stems $\geq 2.5 \mathrm{~cm}$ in diameter at breast height $[\mathrm{DBH}]$ ) were Abies balsamea (L.) Mill. (35.1\%), Betula papyrifera (25.3\%), Picea mariana (14.2\%), Populus tremuloides Michx. (12.8\%), and Picea glauca (6.4\%). All sites were closed canopy (at least 25 years of age post disturbance) and they spanned a range of ages ( 25 to 147 years old based on the Forest 
Resource Inventory [OMNR unpubl.]) and multi-cohort classes (see below) based on classifications by B. Kuttner (unpubl.) and on ground-based visual assessments. The area has been under forest management since the early $20^{\text {th }}$ century; as a result, only three sites were of natural (fire) origin. The majority of the sites were clearcut using horse-logging $(n=34)$; the remainder were clearcut more recently using mechanized systems $(n=8)$.

Centres of the study sites were at least $100 \mathrm{~m}$ from the nearest road and $1 \mathrm{~km}$ from the next nearest site. Centres were placed randomly within a forest stand as delineated on the FRI with the proviso that they fell in the centre of a 100-m-radius circle within the stand. To take advantage of existing habitat data where possible, site centres coincided with the centres of existing OMNR Permanent Growth Plots (PGP; Hayden et al. 1995). When PGP centres fell within $100 \mathrm{~m}$ of a road, the PGP centre was used as a "satellite" habitat station (see below) and the actual site centre was $50 \mathrm{~m}$ away to ensure a distance of the site centre of at least $100 \mathrm{~m}$ from the nearest road.

\section{Habitat sampling}

Habitat measurements were taken during July and August, 2007. We chose habitat variables thought to be important to birds, with a focus on the three-dimensional structure of the forest (e.g., Imbeau et al. 1999) and measurements of coarse woody debris (e.g., Gagné et al. 2007). As succinct measures of a stand's multi-cohort structure, we used parameters (scale and shape) of Weibull functions fit to live tree diameter distribution (expressed as densities for each diameter class). These parameters figure prominently in methods to assign cohort types and vary systematically as a function of the number of tree cohorts present in a stand, from even-aged stands with a single tree cohort and a relatively narrow, bell-shaped distribution of stem diameters, to uneven-aged stands with multiple tree cohorts that give rise to an inverse-J diameter distribution (e.g., Nguyen 2000, Boucher et al. 2003). The scale parameter increases as the diameter distribution shifts to the right, indicative of larger tree sizes, whereas the shape parameter varies according to the shape of the diameter distribution, from bell-shaped to a negative exponential distribution. Live trees were sampled at four stations at each site; namely, the site centre and three satellite stations each $50 \mathrm{~m}$ from the site centre in the form of an equilateral triangle. At the site centre, to conform with the standard provincial specifications (see Hayden et al. 1995), all live stems $\geq 2.5 \mathrm{~cm}$ in diameter at breast height (DBH) were sampled within a $400-\mathrm{m}^{2}$ circular plot (radius of $11.28 \mathrm{~m}$ ). At the three satellite stations, stems $>10 \mathrm{~cm} \mathrm{DBH}$ were sampled via prism sweeps (Basal Area Factor 2). Tree densities were calculated at each of the four stations in $1-\mathrm{cm}$ DBH classes and were averaged across the four stations for stems $>10 \mathrm{~cm} \mathrm{DBH}$ (for stems $<10 \mathrm{~cm} \mathrm{DBH}$, only the centre sample was used). Prism data were converted to densities following Thompson et al. (2006). Because only trees with $\mathrm{DBH}>2.5 \mathrm{~cm}$ were measured, $2.5 \mathrm{~cm}$ was subtracted from each $\mathrm{DBH}$ to account for the empty probability space. The Weibull function was fitted to the distribution of diameters (for $1-\mathrm{cm}$ $\mathrm{DBH}$ bins) for each site using the CAPABILITY procedure in SAS v. 8.2 and the scale and shape of the curve were estimated using maximum likelihood (the location parameter was set to zero). Based on these parameter values, sites were classified into four cohort classes by use of the mixedwood shape and scale cutoffs in Sharkey and Malcolm (unpubl.).

Other structural habitat measurements focused on measurements of vertical and horizontal structural complexity and on variation in the quantity and quality of dead wood resources. Each live tree measured was assigned one of nine canopy classes (emergent, dominant, co-dominant, intermediate, overtopped/ suppressed, understorey, open understorey, open-grown, or anomaly) (Hayden et al. 1995). From these data, canopy class diversity was calculated using the Shannon diversity index ( $H$; Magurran 1988). We also calculated canopy class richness; however, because richness increased partly due to the number of stems sampled (i.e., a sampling effect), we used a simple rarefaction procedure to measure richness independently of the number of stems. Specifically, the number of canopy classes at a site was plotted against the number of stems sampled and the residuals from linear regression were used as the richness measurement.

To measure vertical complexity and horizontal heterogeneity of foliage (sensu August 1983), we used the method developed by Hubbel and Foster (1986) and modified by Malcolm (1994). This was done by establishing three, 100-m long transects from the site centre that intersected the satellite stations. At $2.5-\mathrm{m}$ intervals along each transect, an observer sighted vertically along a $2.5-\mathrm{m}$ long pole and estimated foliage density scores along the sighting for each of the following height intervals: $0-2.5,2.5-5,5-10,15-20,20-25$, 25-30 and 30-35 m. The density scores were as follows: $0=0-10 \%, 1=10-50 \%, 2=50-75 \%$, and $3=75-100 \%$. Heights were periodically checked using an optical rangefinder. Density scores were then converted to foliage thickness (in $\mathrm{m}$ ) by multiplying the midpoint of the score's percent range by the total thickness (in $\mathrm{m}$ ) of the height interval in question. Foliage thickness in intervals with a score of 0 was assumed to be zero. To reduce the number of variables for these data, we conducted a Principal Components Analysis (PCA) on the site-specific mean thicknesses of the various height intervals (on the correlation matrix). In this matrix, rows were sites and columns were height intervals. The first two PCA axes accounted for 55\% of the variance and showed that measurements within three strata (0-10 m [understorey], 10-15 m [lower canopy], and 15-35 m [upper canopy]) were correlated with each other. Accordingly, vegetation thicknesses within these three strata were summed. For each of these strata, mean thickness and within-site variance and semivariance (grain) were calculated for each site. Because the latter two measurements were highly correlated with the mean, we used regression across the sites to partial out the effects of the mean. The residual variance and residual semivariance were then used in analyses rather than the raw measurements. Based on these data, we also calculated maximum and mean canopy height for each site and the residual variance and residual semivariance of canopy height. Canopy heights at each $2.5-\mathrm{m}$ interval were assigned the mean height of the highest interval that had a foliage score greater than zero. Finally, from the mean thicknesses obtained for the seven height intervals for each site, foliage height diversity was calculated using the Shannon index of diversity $\left(H^{\prime}=-\sum p_{\mathrm{i}} \ln \right.$ $p_{\mathrm{i}}$, where $p_{\mathrm{i}}$ represents the proportion of the total foliage thickness in height interval $i$ ).

Shrub stems, defined as woody-stemmed plants $<2.5 \mathrm{~cm}$ in $\mathrm{DBH}$ and shorter than $1.3 \mathrm{~m}$ in height, were counted within one 2.5- $\mathrm{m}$ radius circular plot at each of the four stations.

Standing dead trees (snags) $>10 \mathrm{~cm}$ DBH were sampled in the same way as live stems and each stem was assigned a decomposition class of 1 to 5 (Hayden et al. 1995). Coarse woody debris sampling was conducted along four, 15-m long transects 
originating from the site centre along the cardinal directions. Along each transect, intercepted coarse woody debris was identified to species and decay class (Hayden et al. 1995) and the diameter at the point of intersection measured.

Finally, site types as defined by the Northeast Forest Ecosystem Classification (FEC) system (Taylor et al. 2000) were determined at the site centres. The net effect was, for each stand, measurements of stand age, Weibull scale and shape, cohort class, FEC site type, and 21 habitat structure variables (Appendix 2).

\section{Bird sampling}

Bird communities were sampled at site centres during the 2007 breeding season using two methods: playback and passive point counts. Because of earlier breeding activity and relatively low detection probabilities from passive point counts, cavity nesting species (Downy Woodpecker, Hairy Woodpecker, Yellow-bellied Sapsucker, Northern Flicker, Pileated Woodpecker, Brown Creeper, Red-breasted Nuthatch, Boreal Chickadee, and Blackcapped Chickadee) were surveyed at each site once by playback during the period May 21 to June 5, 2007 (See Appendix 3 for scientific names). Playback was conducted on calm days (wind speed $<15 \mathrm{~km} \mathrm{~h}^{-1}$ ) with no precipitation between sunrise and noon. Prior to each playback session a portable Pignose guitar amplifier (Model 7-100, Pignose-Gorilla, Las Vegas) attached to a portable CD player was set up on the ground with a standardized volume level (a level that could easily be heard by a human at a distance of $100 \mathrm{~m}$, as determined from field tests before the surveys began). After a five-minute waiting period, approximately two minutes of recorded calls and drumming (woodpeckers only) for each species was followed by approximately two minutes of silence. Only birds encountered during the species' designated time (playback or silence) were recorded. For each species, the number of individuals detected within an estimated $100 \mathrm{~m}$ was recorded.

Passive point counts were conducted between June 6 and July 4, 2007. Each site centre was visited three times between dawn and 9:30 am on calm mornings with no precipitation. Each site was visited once during each third of the sampling season and efforts were made to sample each site during early, mid, and late parts of the morning sampling period. At each visit, two consecutive five-minute listening periods were spent during which time the numbers of individuals seen and heard for each species was recorded. Each individual's distance from the point count centre was estimated and only those within $100 \mathrm{~m}$ of the point count centre were counted.

For each species, the maximum number of individuals detected on any of the six, five-minute point counts or the playback (for cavity nesters) was calculated and was used as an estimate of abundance (the maximum number of territories overlapping the $100-\mathrm{m}$ circle at each site). Species not associated with forested habitats, such as
Common Loon and Belted Kingfisher, were dropped from the analyses.

In addition to the whole community, we also analyzed matrices of species' abundances for various feeding guilds and forest-type associations based on information in Poole (2009; see Appendix 3). Species were assigned to six feeding guilds and three forest-type groupings (Table 1).

\section{Data analysis}

For the entire bird community, a Principal Components Analysis on species abundances (species were centered and standardized) was conducted. Structural variables that had strong relationships (axis scores of $\geq 0.4$ ) or that were significant $(P<0.05$; Monte Carlo Permutation test with 9999 permutations) on their own or in a forward selection in redundancy analysis (RDA) were plotted passively. In addition, using RDAs on the entire bird community (again centered and standardized), we compared the explanatory power of the two Weibull parameters against all possible pairs of structural habitat variables (21 variables, giving 210 possible pairs). To measure the explanatory power of Weibull parameters and stand age, RDAs on the various bird matrices were conducted and the variance was decomposed (Borcard et al. 1992, Drapeau et al. 2000) in CANOCO for Windows (v. 4.5) by use of Monte Carlo permutation tests with 9999 permutations.

\section{Results}

\section{Bird Communities}

In total, 53 species of forest birds were detected during the playback and point count sampling. The top ten species overall, by mean abundance, were Red-eyed Vireo (2.29), Red-breasted Nuthatch (1.78), Ovenbird (1.36), Magnolia Warbler (1.11), Yellow-bellied Sapsucker (1.09), Black-capped Chickadee (1.02), Yellow-rumped Warbler (0.76), Pine Siskin (0.73), Hermit Thrush (0.73), and Golden-crowned Kinglet (0.73). See Appendix 3 for scientific names and overall abundances.

Table 1. Feeding guild and forest-type breakdown for bird communities in boreal mixedwood stands of northeastern Ontario. Species assignments are in Appendix 3.

\begin{tabular}{|c|c|c|c|}
\hline Guild name & Guild type & $\begin{array}{l}\text { Number } \\
\text { of species }\end{array}$ & Description \\
\hline Ground & Feeding & 9 & $\begin{array}{l}\text { Insectivorous species that feed on or near the } \\
\text { ground }\end{array}$ \\
\hline Shrub & Feeding & 14 & Insectivorous species that feed in the shrub layer \\
\hline Canopy & Feeding & 13 & Insectivorous species that feed in the canopy \\
\hline Bark & Feeding & 7 & $\begin{array}{l}\text { Insectivorous species that feed on the trunks or } \\
\text { limbs of trees }\end{array}$ \\
\hline Generalist & Feeding & 5 & $\begin{array}{l}\text { Species that are not associated with any } \\
\text { particular feeding location or food type }\end{array}$ \\
\hline Seed & Feeding & 5 & Granivorous species that feed on tree seed crops \\
\hline Deciduous & Forest type & 13 & $\begin{array}{l}\text { Species favouring forests dominated by } \\
\text { deciduous tree species }\end{array}$ \\
\hline Mixedwood & Forest type & 16 & $\begin{array}{l}\text { Species favouring mixedwoods or without } \\
\text { preference for deciduous- or coniferous- } \\
\text { dominated forests }\end{array}$ \\
\hline Coniferous & Forest type & 24 & $\begin{array}{l}\text { Species favouring forests dominated by } \\
\text { coniferous tree species }\end{array}$ \\
\hline
\end{tabular}




\section{Cohort classification}

Use of the Weibull-based cutoffs resulted in four structural cohort classes (Fig. 1). Cohort class 1 sites exhibited a relatively normal distribution of diameters; class 2 sites showed a rightskewed normal distribution of diameters; and class 3 and 4 sites had distributions approaching an inverse-J shaped curve, with the main difference between classes 3 and 4 being the longer tail shown by class 4 sites. Cohort class 4 sites had the highest FRI-based age (mean age $=85$ years), followed by class 3 (mean age $=74$ years), class 2 (mean age $=72$ years) and class 1 (mean age $=52$ years). An ANOVA on mean age ranks was significant among the cohort classes $\left(\mathrm{F}_{3,44}=0.9, P=0.008\right)$ with Tukey's Studentized range test indicating significant differences between cohort classes 1 and 2 and between cohort classes 1 and $4(\alpha=0.05)$.

\section{Bird community variation as a function of habitat features}

In a PCA of all bird species (Fig. 2a, b), sites in cohort classes 1,3 , and 4 were arrayed in the bottom, left, and upper right of the biplot, respectively, whereas cohort class 2 sites were scattered throughout the plot. The first PCA axis appeared to be partly a coniferous/deciduous gradient, with positive values associated with coniferous species (Yellow-rumped Warbler, Golden-crowned Kinglet, Ruby-crowned Kinglet, Nashville Warbler, and Yellow-bellied Flycatcher) and negative values associated with more deciduous species (such as Ovenbird, Downy Woodpecker, Black-throated Green Warbler, Red-eyed Vireo, Northern Parula, and Blackburnian Warbler). Positive associations with the second PCA axis were shown by Purple

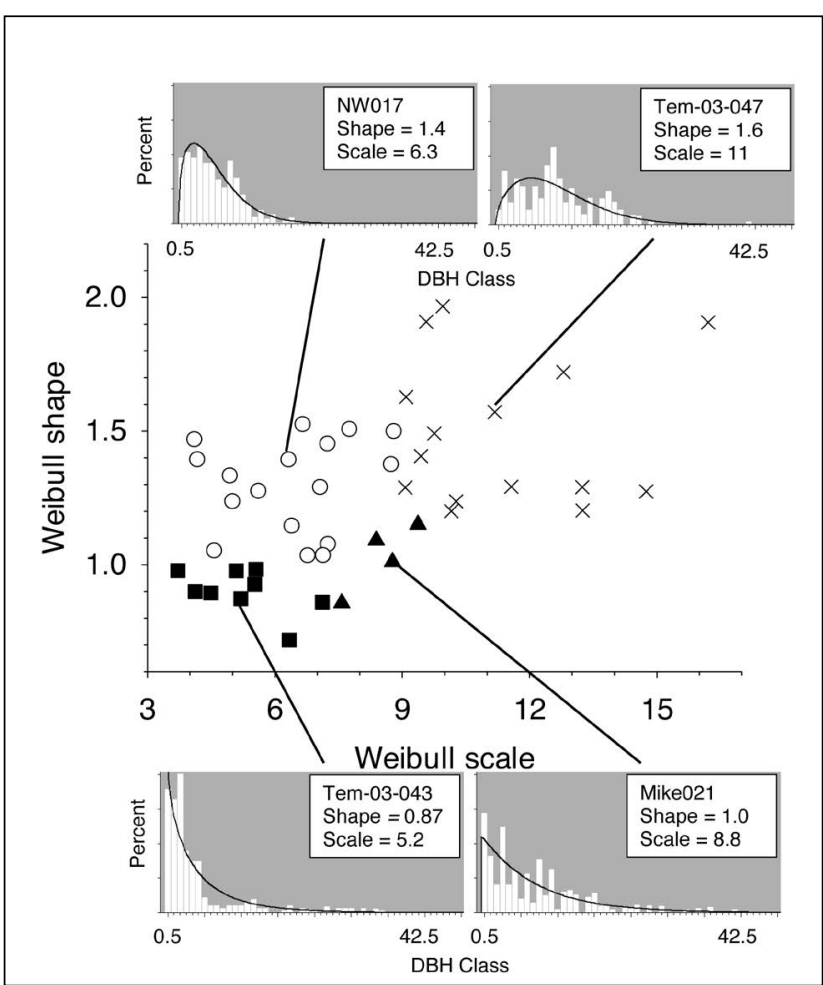

Fig. 1. Mixedwood sites in boreal northeastern Ontario plotted according to measurements of Weibull scale and shape of the tree diameter distribution. Symbols are as follows: circle $=$ cohort class 1; " $x$ " = cohort class 2; triangle = cohort class 3; square = cohort class 4. Example histograms with fitted Weibull curves are shown for one site in each cohort class.
Finch, Red-breasted Nuthatch, Winter Wren, Yellow-bellied Sapsucker, and, to a lesser extent, Ovenbird, Northern Parula, and Blackburnian Warbler. A negative association was shown by Golden-crowned Kinglet.

Highly significant $(P<0.01)$ correlates of the entire bird community included canopy height, foliage thickness of the canopy layer, foliage height diversity, cohort class, and Weibull scale (Table 2). These same variables, or a subset of them, also tended to be significant for species associated with deciduous forests and the canopy and bark feeding guilds. For these three groups, additional significant correlates were recent CWD (for deciduous species and the canopy guild) and forest age,

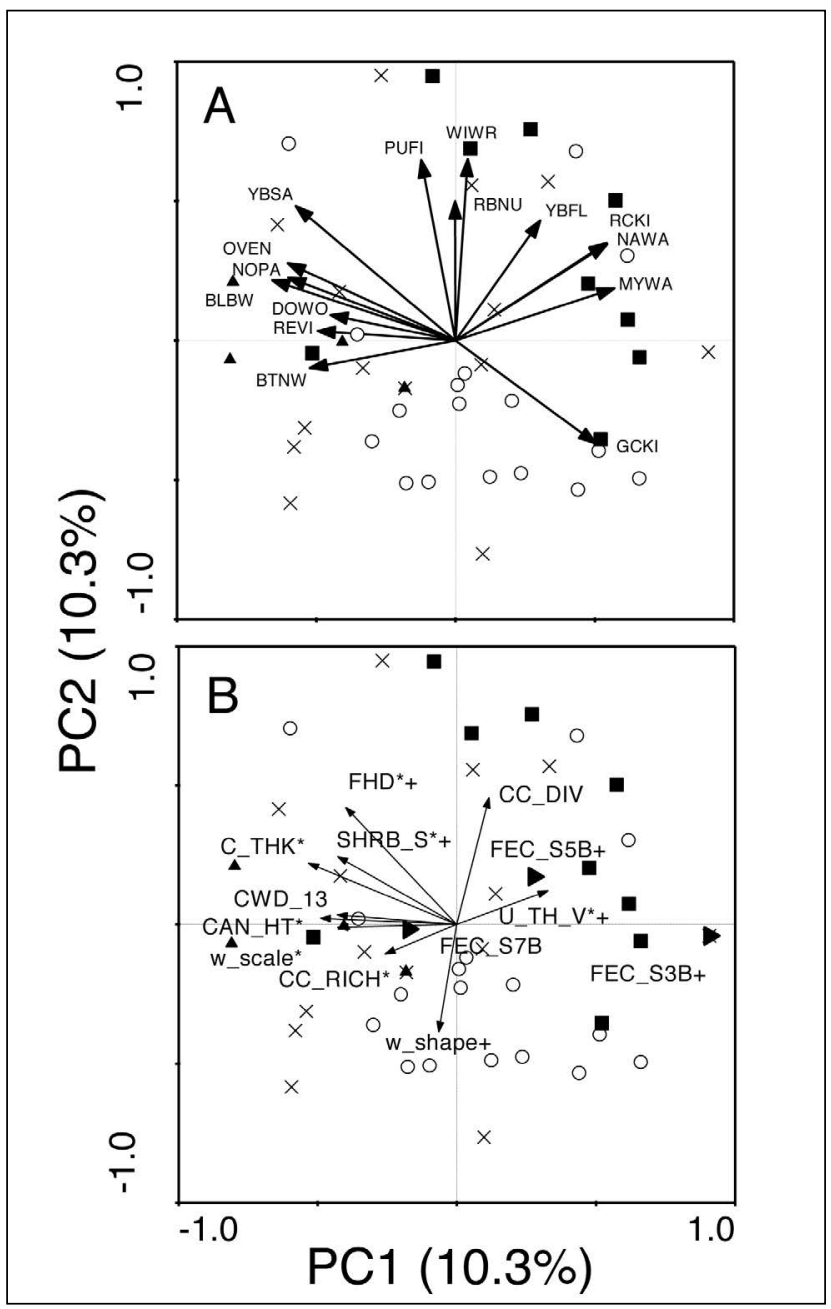

Fig. 2. Axes 1 and 2 from a principal components analysis on the entire bird community of mixedwood sites sampled in boreal northeastern Ontario. In part A, sites are symbolized according to their cohort class (circle = cohort class 1; " $x$ " = cohort class 2 ; triangle $=$ cohort class 3 ; square $=$ cohort class 4 ) and species vectors are shown for the fifteen bird species with the longest vectors. In part $B$, structural habitat variables that were significant in explaining community variation are plotted passively ${ }^{*}$ = variable significant on its own; + = variable significant and included in forward selection of best model; vectors are for continuous variables and right-pointing triangles are for nominal variables). See appendices 1 and 2 for species and variable codes; one outlier site (NW028) was removed from the bird and habitat matrices prior to analysis. Note that SHRB_STM = SHRB_S and that U_THK_V $=U_{-}$TH_V. 
Weibull shape, and shrub density (for the bark guild). Other forest-type groupings and feeding guilds showed fewer correlations (one or two highly significant correlations each). Across all matrices, variables with the highest predictive power of bird community composition were canopy height (seven significant correlations); foliage height diversity and cohort class (six significant correlations each); and canopy thickness, Weibull scale, and shrub density (five significant correlations each).

When forward selection was used to select variables, several of the above variables again figured prominently (canopy thickness, cohort type, and foliage height diversity; Table 3). Variables that tended to show greater prominence than earlier (i.e., tended to be selected, despite having generally low correlations in isolation) were FEC forest types, understory thickness variance, and canopy class richness.

In comparing the explanatory power of the two Weibull parameters against all possible pairs of structural habitat variables, the Weibull parameters performed relatively well $(7.2 \%$ of variance explained for the entire bird matrix; $P<0.001$ ) and outperformed $90 \%$ of the variable pairs (188 of 210 pairs). In every variable pair that outperformed the Weibull parameters, at least one of three structure variables was present: canopy height, thickness of the upper canopy stratum, and foliage height diversity. Excluding pairs that consisted of only these variables, the other variable in the pair was in most cases related to the second moment of the distribution of a habitat variable rather than the first moment; that is, it reflected the shape of the distribution (variance) rather than the position (mean). This was true in 14 of the 19 pairs. Variables in these cases were: variance of upper canopy stratum thickness, canopy class richness, variance of understory stratum thickness, variance of canopy height, canopy class diversity, and variance of lower canopy stratum thickness.

\section{Decomposition of variance for Weibull parameters and forest age}

When the relative contributions of the two Weibull parameters were examined via decomposition of variance, Weibull

Table 2. Probability values from permutation tests of the significance of individual habitat variables in explaining variation in the entire bird community and habitat and feeding guilds in boreal mixedwood stands of northeastern Ontario.

\begin{tabular}{|c|c|c|c|c|c|c|c|c|}
\hline Variable $^{a}$ & All birds & Deciduous & Mixedwood & Coniferous & Ground guild & Shrub guild & Canopy guild & Bark guild \\
\hline Age & ns & ns & ns & ns & ns & ns & ns & 0.006 \\
\hline CAN_HT & $<0.001$ & $<0.001$ & ns & 0.015 & 0.03 & 0.008 & 0.01 & 0.006 \\
\hline CAN_HT_V & ns & ns & ns & ns & ns & ns & ns & 0.007 \\
\hline CAN_HT_S & ns & ns & ns & ns & ns & ns & ns & ns \\
\hline U_THK & ns & ns & ns & ns & 0.043 & ns & ns & ns \\
\hline U_THK_V & 0.01 & ns & ns & 0.023 & ns & ns & ns & 0.037 \\
\hline U_THK_S & ns & ns & ns & ns & ns & ns & ns & ns \\
\hline M_THK & ns & ns & ns & ns & ns & 0.038 & ns & ns \\
\hline M_THK_V & ns & ns & 0.037 & ns & ns & ns & ns & 0.027 \\
\hline M_THK_S & ns & ns & ns & ns & ns & ns & ns & ns \\
\hline C_THK & $<0.001$ & $<0.001$ & ns & ns & ns & 0.038 & 0.007 & 0.001 \\
\hline C_THK_V & 0.041 & ns & ns & ns & ns & ns & ns & ns \\
\hline C_THK_S & ns & ns & ns & ns & ns & ns & ns & ns \\
\hline FHD & 0.001 & $<0.001$ & ns & ns & 0.045 & ns & 0.002 & $<0.001$ \\
\hline w_scale & 0.005 & 0.003 & ns & 0.049 & ns & 0.007 & 0.034 & ns \\
\hline w_shape & ns & ns & 0.035 & ns & ns & ns & ns & $<0.001$ \\
\hline CC_RICH & 0.028 & 0.041 & ns & ns & 0.006 & ns & ns & ns \\
\hline CC_DIV & ns & ns & ns & ns & ns & ns & ns & ns \\
\hline LV_BA & ns & ns & 0.038 & ns & ns & ns & 0.044 & 0.015 \\
\hline SNG_BA & ns & ns & ns & ns & ns & ns & 0.049 & ns \\
\hline CWD_13 & ns & $<0.001$ & ns & ns & 0.043 & ns & 0.002 & ns \\
\hline CWD_45 & ns & ns & ns & ns & ns & ns & ns & ns \\
\hline SHRB_STM & 0.02 & 0.017 & 0.038 & ns & 0.035 & ns & ns & 0.004 \\
\hline \%_DECID & ns & 0.014 & ns & ns & ns & ns & ns & ns \\
\hline Cohort & 0.002 & 0.005 & ns & 0.058 & ns & ns & 0.002 & 0.003 \\
\hline FEC & 0.045 & ns & $<0.001$ & ns & ns & ns & ns & 0.019 \\
\hline
\end{tabular}

a See Appendix 2 for variable code definitions. 
Table 3. Order and significance of variables selected in forward-selection permutation tests explaining community structure for the entire bird community and various habitat and feeding guilds in boreal mixedwood stands in northeastern Ontario. Significance is indicated by asterisks $\left[\boldsymbol{P}<0.001\left[{ }^{*}{ }^{*}\right], P<0.01\left[{ }^{\star *}\right]\right.$, and $\boldsymbol{P}<0.05\left[{ }^{*}\right]$. $^{\text {a }}$

\begin{tabular}{|c|c|c|c|c|c|c|c|}
\hline All birds & Deciduous & Mixedwood & Coniferous & Ground guild & Shrub guild & Canopy guild & Bark guild \\
\hline $\begin{array}{l}\text { C_THK } \mathrm{THK}^{* * *} \\
\mathrm{CHT}^{* *}\end{array}$ & $\begin{array}{l}\text { C_THK }{ }^{* * *} \\
\text { CWD_13 } 13^{* *}\end{array}$ & $\begin{array}{l}\text { FEC_S3B* } \\
\text { FEC_S5B }^{\star *}\end{array}$ & $\begin{array}{c}\text { FEC_S7B }^{* *} \\
\mathrm{CHT}^{*}\end{array}$ & $\begin{array}{l}\text { FEC_S7B }{ }^{* *} \\
\text { CC_RICH } \\
\end{array}$ & CAN_HT ${ }^{* *}$ & $\begin{array}{l}\text { CWD_13*** } \\
\text { FEC_S3B }\end{array}$ & $\begin{array}{c}\mathrm{FEC}_{1} \mathrm{~S}_{3} \mathrm{~B}^{*} \\
\mathrm{FHD}^{* * *}\end{array}$ \\
\hline $\mathrm{FHD}^{*}$ & $\mathrm{CHT}^{*}$ & SHRB_STM ${ }^{*}$ & $\mathrm{FHD}^{*}$ & & & $\mathrm{CHT}^{*}$ & FEC_S5B $B^{\star \star *}$ \\
\hline FEC_S3B* & & U_THK ${ }^{*}$ & & & & SNG_BA* & w_shape $e^{\star * \star}$ \\
\hline U_THK_V ${ }^{*}$ & & U_THK_V ${ }^{*}$ & & & & FEC_S9B ${ }^{*}$ & SHRB_STM $^{* *}$ \\
\hline CC_RICH ${ }^{*}$ & & C_THK_V ${ }^{*}$ & & & & U_THK_V ${ }^{*}$ & CC_RICH ${ }^{*}$ \\
\hline \multirow[t]{6}{*}{ CAN_HT_V* } & & CC_RICH ${ }^{*}$ & & & & C_THK ${ }^{*}$ & U_THK_V* \\
\hline & & w_shape ${ }^{\star}$ & & & & & \\
\hline & & FEC_S9B ${ }^{\star *}$ & & & & & \\
\hline & & FEC_S5A* & & & & & \\
\hline & & $\mathrm{FHD}^{*}$ & & & & & \\
\hline & & C_THK ${ }^{*}$ & & & & & \\
\hline
\end{tabular}

${ }^{\text {a }}$ See Appendix 2 for variable code definitions.

scale was significant on its own for more feeding guilds and forest-type groupings than Weibull shape (five vs. two groups; Table 4). The bark guild and, to a lesser extent mixedwood species, were unusual relative to the other species groupings in that the shape parameter explained more variance than the scale parameter. One or the other parameter was a significant predictor for all birds and for all of the species groupings, with the exception of the ground guild ( $P=0.09$ for Weibull scale). As shown by their nearly perpendicular vectors in Fig. $2 b$, the two variables were statistically independent, and hence when one or the other parameter was significant by itself, it also tended to be significant even when variation due to the other parameter had already been accounted for. The exception was Weibull scale for the ground guild, which was not significant by itself $(P=0.09)$, but was significant when Weibull shape was included in the model $(P=0.03$; Table 4$)$.

The two Weibull parameters outperformed stand age as a correlate of bird community structure: they were significant for all species and for four of the species groupings $(0.05<P<0.10$; Table 5). By contrast, age was significant for only one group (bark guild). When age was entered into the model, the Weibull parameters remained significant for all species and for three of the species groupings whereas with the Weibull parameters entered into the model, age was never significant (Table 5).
Table 4. Decomposition of variance of Weibull shape and Weibull scale in explaining community structure for the entire bird community and various habitat and feeding guilds in boreal mixedwood stands in northeastern Ontario. ( $P$ values in brackets).

\begin{tabular}{lcccccc}
\hline & $\begin{array}{c}\text { Weibull shape and } \\
\text { scale together }\end{array}$ & $\begin{array}{c}\text { Weibull } \\
\text { shape }\end{array}$ & $\begin{array}{c}\text { Weibull } \\
\text { scale }\end{array}$ & $\begin{array}{c}\text { Unique } \\
\text { to shape }\end{array}$ & $\begin{array}{c}\text { Unique } \\
\text { to scale }\end{array}$ & Shared \\
\hline All birds & 7.2 & 2.7 & 4 & 3 & 4.3 & -0.3 \\
Deciduous & $(0.001)$ & $(\mathrm{ns})$ & $(0.003)$ & $(\mathrm{ns})$ & $(<0.001)$ & \\
& 9.3 & 2.7 & 5.7 & 3.5 & 6.6 & -0.8 \\
Mixedwood & $(0.001)$ & $(\mathrm{ns})$ & $(0.002)$ & $(\mathrm{ns})$ & $(<0.001)$ & \\
& 7 & 3.9 & 2.9 & 4.1 & 3.1 & -0.2 \\
Coniferous & $(0.027)$ & $(0.04)$ & $(\mathrm{ns})$ & $(0.024)$ & $(\mathrm{ns})$ & \\
& 6 & 2.3 & 3.7 & 2.3 & 3.7 & 0 \\
Ground guild & $(\mathrm{ns})$ & $(\mathrm{ns})$ & $(0.044)$ & $(\mathrm{ns})$ & $(0.05)$ & \\
& 6.7 & 1.4 & 4.1 & 2.6 & 5.3 & -1.2 \\
Shrub guild & $(\mathrm{ns})$ & $(\mathrm{ns})$ & $(\mathrm{ns})$ & $(\mathrm{ns})$ & $(0.025)$ & \\
& 7.6 & 2.7 & 5.3 & 2.3 & 4.9 & 0.4 \\
Canopy guild & $(0.023)$ & $(\mathrm{ns})$ & $(0.007)$ & $(\mathrm{ns})$ & $(0.012)$ & \\
& 7.9 & 2 & 4.5 & 3.4 & 5.8 & -1.3 \\
Bark guild & $(0.017)$ & $(\mathrm{ns})$ & $(0.032)$ & $(\mathrm{ns})$ & $(0.003)$ & \\
& 12.8 & 8.5 & 4 & 8.8 & 4.3 & -0.3 \\
& $(<0.001)$ & $(<0.001)$ & $(\mathrm{ns})$ & $(<0.001)$ & $(0.048)$ & \\
\hline
\end{tabular}


Overall, we found support for the concept of using Weibull parameters as coarse filter features for describing structural habitat variation. For example, they outperformed age, which, along with forest type, has been used as a key variable to describe and model boreal bird habitats (e.g., D'Eon and Watt 1994). At the same time, however, several variable pairs outperformed the Weibull parameters as coarse filters of bird community variation. These pairs always included canopy height, thickness of the upper canopy stratum, or foliage height diversity. Thus, variables that directly measured the canopy performed better than Weibull scale, which was based on tree diameter distributions. Of particular interest in this study was the finding that Weibull shape sometimes provided explanatory value independently of Weibull scale, which suggests that diameter class heterogeneity may be an important descriptor of bird habitat variation. Indeed, the importance of a measure of habitat heterogeneity as a coarse filter to explain bird community variation, similar to Weibull shape, was confirmed in the variable pairs that outperformed the Weibull parameters. The utility of such purely structural features in describing habitat variation, with the potential for silvicultural manipulation of these features, holds out promise for application of multi-cohort management to conserve bird communities. That is, it may be possible to "guide" stands of varying ages into particular diameter distributions in order to manage or create habitats favourable for particular species or bird communities.

Certain caveats of the current study bear mentioning. Most of the stands sampled for this study were less than 100 years old, and the small range of stand ages may have provided low power for examining age effects. For instance, Drapeau et al. (2003) found differences in abundances of several species in stands 100 to 120 years post disturbance when compared to stands greater than 200 years post disturbance in the black spruce forest of northwestern Québec. With a strictly structural cohort class definition, stand age and structure are decoupled to some

Table 5. As Table 4 except that decomposition of variance is shown for Weibull parameters (scale and shape together) and stand age.

\begin{tabular}{lcccccc}
\hline & $\begin{array}{c}\text { Weibull and } \\
\text { age together }\end{array}$ & Weibull & Age & $\begin{array}{c}\text { Unique to } \\
\text { Weibull }\end{array}$ & $\begin{array}{c}\text { Unique } \\
\text { to age }\end{array}$ & Shared \\
\hline All birds & 9.1 & 7 & 2.5 & 6.6 & 2.1 & 0.4 \\
& $(0.008)$ & $(0.001)$ & $(\mathrm{ns})$ & $(0.004)$ & $(\mathrm{ns})$ & \\
Deciduous & 10.3 & 9.3 & 1.9 & 8.4 & 1 & 0.9 \\
& $(0.02)$ & $(0.001)$ & $(\mathrm{ns})$ & $(0.004)$ & $(\mathrm{ns})$ & \\
Mixedwood & 9.5 & 7 & 2.7 & 6.8 & 2.5 & 0.2 \\
& $(0.039)$ & $(0.027)$ & $(\mathrm{ns})$ & $(0.036)$ & $(\mathrm{nns})$ & \\
Coniferous & 8 & 6 & 2 & 6 & 2 & 0 \\
& $(\mathrm{~ns})$ & $(\mathrm{ns})$ & $(\mathrm{ns})$ & $(\mathrm{ns})$ & $(\mathrm{ns})$ & \\
Ground guild & 9.1 & 6.7 & 2.1 & 7.1 & 2.4 & -0.4 \\
& $(\mathrm{~ns})$ & $(\mathrm{ns})$ & $(\mathrm{ns})$ & $(\mathrm{ns})$ & $(\mathrm{ns})$ & \\
Shrub guild & 8.8 & 7.6 & 1.2 & 7.6 & 1.2 & 0 \\
& $(\mathrm{~ns})$ & $(0.023)$ & $(\mathrm{ns})$ & $(0.025)$ & $(\mathrm{nns})$ & \\
Canopy guild & 9.4 & 7.9 & 2.5 & 6.9 & 1.5 & 1 \\
& $(\mathrm{~ns})$ & $(0.017)$ & $(\mathrm{ns})$ & $(\mathrm{ns})$ & $(\mathrm{ns})$ & \\
Bark guild & 16.8 & 12.8 & 6.6 & 10.2 & 3.9 & 2.7 \\
& $(<0.001)$ & $(<0.001)$ & $(0.007)$ & $(0.002)$ & $(\mathrm{nns})$ & \\
\hline
\end{tabular}

extent; for example, disturbance scenarios are possible in which a relatively young stand has a relatively uneven-aged diameter distribution. That being said, the diameter distributions associated with the different cohort classes would be expected to correlate to some extent with age, which was true here. While diameter distribution describes many aspects of stand structure, there may be no substitute for stand age in determining the development of certain features. For example, managers should be able to guide stands into a certain diameter distribution (and thus structural cohort class); however, specific treatments might be needed to create certain age-dependent habitat features such as snags, which are frequently identified as a key attribute of mature boreal forest for many wildlife species and guilds (Drapeau et al. 2009). Indeed, we found evidence that stand age was a relatively important feature for explaining variability of the bark-feeding guild, which could reflect certain snag features or the absolute sizes of trees.

Another issue with respect to the ability of silvicultural interventions to construct structural variability is the possibility of associated changes in deciduous/coniferous proportions. Drapeau et al. (2000) point to such change as the largest anthropogenic alteration at the landscape level from an avian perspective in boreal mixedwoods. They warn that stand-level alterations are probably less important than landscape-level changes in which deciduous stands increasingly replace naturalorigin mixed and coniferous stands. At the stand level, Hobson and Bayne (2000) also noted that management-related changes in the composition of forest types would have serious consequences to birds (see also Jackson et al. 2000).

Certainly, the application of multi-cohort management is more complicated than conventional management in that we have limited experience and understanding of how boreal stands will respond to alternative silvicultural treatments, such as selection cuts to favour shade-tolerant conifers. Moreover, it remains to be determined to what extent such treatments emulate the structural variation important to biodiversity (see Deans et al. 2005, for example).

\section{Diameter distributions and the bird communities of different forest types and feeding guilds}

In some cases, structural features that one might expect to be associated with the various guilds explained only small amounts of the community variation. For example, ground feeding birds might be expected to be linked to structural features associated with understorey thickness, shrub density, and coarse woody debris availability. Because cohort class 1 and 4 sites were associated with high understorey thickness and shrub density, we expected the ground-feeding guild to be associated with these cohort classes, but this was not the case. Similarly, we expected that the shrub-feeding guild would be associated with shrub density, understorey thickness, lower canopy thickness, and variance in lower and upper canopy thickness (creating openings), but only lower canopy thickness was a significant predictor for the guild. For the canopy-feeding guild, we 
expected structural features associated with the canopy to be important, and indeed, canopy height, upper canopy thickness, foliage height diversity, and Weibull scale were significant predictors of this guild. Finally, one might expect the bark-feeding guild to be associated most with snag availability. However, snag basal area was not a significant predictor for the guild, possibly a result of the sampling design (relatively low numbers of snags were detected at all sites) or the relatively young age of most stands. There is some evidence that Brown Creepers and Pileated Woodpeckers, two species often associated with old-growth forests and large-diameter snags (Bull and Jackson 1995, Hejl et al. 2002), were associated with later cohort classes.

When birds were divided into forest-type associations, the group of birds associated with mixedwood stands was best explained by structural variables, whereas birds associated with coniferous stands were explained most poorly by structural variables. It may be that because deciduous stands can be more complex than the simple canopy structure of boreal coniferousdominated forests, stand structure becomes more important for wildlife in boreal stands containing a deciduous element. However, power for examining responses among coniferous species was also presumably low in that all stands had a relatively strong deciduous component.

Variation in the abundances of canopy- and bark-feeding birds was highly correlated with variation in forest structure. Important structural features in this regard included canopy class richness, variance of understorey thickness, foliage height diversity, mean upper canopy thickness, and shrub stem density. This suggests that canopy-feeding birds and bark-feeding birds will be most sensitive to changes in forest structure, whereas shrub-feeding and ground-feeding birds will be least sensitive to changes in forest structure. This would suggest that Weibull shape would also be a significant predictor, but it was significant only for the bark-feeding and mixedwood habitat guilds. Because bark-feeding birds are potentially the most sensitive to structural changes to their habitat, including the Weibull shape parameter, they are of particular interest to managers. However, it was also evident that passive point counts did not perform as well as targeted playback surveys for these birds, hence future studies should incorporate additional sampling methods for these species.

It would be interesting to compare cohort classes with respect to reproductive success. Philips et al. (2005; see also Van Horne 1983) point out that a species may be equally abundant in various habitats, but that measures such as nest success may show differences between habitats. Dalley et al. (2009) found that species may be found in stands with differing forest management histories, but have very different breeding success rates, depending on the intensity of forest management. For example, Darveau et al. (1997) found that naturally regenerating stands had lower nest predation levels than experimental-strip or clearcut sites.

\section{Management implications}

As noted earlier, Weibull parameters appeared to be better predictors of bird communities than age, and we found that measures of foliage thickness together with measures of foliage heterogeneity performed well as overall predictors of bird community variation, lending support to the idea of structural habitat manipulation through multi-cohort forest management. While stand age is more readily available to forest managers (age is generally a stand attribute in forest resource inventory maps), we have shown here that age alone may not be the best coarse filter of bird community variation. At the same time, the ease of acquiring a suitable metric to be used as a coarse filter must be weighed against its relative value. We caution, however, that none of the variables explained much of the total variation, either for the whole community or for the various species groups. What was apparent, however, was that even in relatively young stands, we found large variation in stand structure, and that this structural heterogeneity is important to bird communities. This structural diversity may be a result of frequent small-scale disturbances that create structural diversity, or of former timber harvesting practices (horse logging) that left enough residual structure to mimic low severity disturbances. There is clearly a need to manage for a diverse range of structural features in order to ensure adequate management of the entire bird (and other) communities. Additionally, because cavity-nesting birds are often associated with older stands that contain more standing dead and dying wood, these important features should be taken into account in management and considered as a key classification parameter for multi-cohort forest management. In future work, more intensive snag surveys would be advised to accurately measure the availability of this important habitat resource. Variation in different feeding guilds was explained by different structural features, but it is apparent that vertical and horizontal heterogeneity generally are important structural features for birds. Finally, there is a need to develop new silvicultural techniques that maintain adequate feeding trees for bark-feeding (Drapeau et al. 2009) and canopy-feeding birds, two guilds that appear to be the most sensitive to structural features.

\section{Acknowledgements}

This research was funded by the Forestry Futures Trust, Tembec Inc., Lake Abitibi Model Forest, Ontario Ministry of Natural Resources and Centres of Excellence, National Science and Engineering Research Council of Canada, Faculty of Forestry of the University of Toronto, and an Ontario Graduate Scholarship. We would like to thank E. Barkley, B. Kuttner, C. Sharkey, S. Thomas, D. Turner, and L. Walton.

\section{References}

Amiro, B., J. Todd, B. Wotton, K. Logan, M. Flannigan, B. Stocks, J. Mason, D. Martell and K. Hirsch. 2001. Direct carbon emissions from Canadian fires, 1959-1999. Can. J. For. Res. 31: 512-525.

August, P.V. 1983. The role of habitat complexity and heterogeneity in structuring tropical mammal communities. Ecology 64: 1495-1507.

Attiwill, P. 1994. The disturbance of forest ecosystems: the ecological basis for conservation management. For. Ecol. Manag. 63: 247-300.

Bergeron, Y., S. Gauthier, M. Flannigan and V. Kafka. 2004. Fire regimes at the transition between mixedwood and coniferous boreal forest in northwestern Quebec. Ecology. 85: 1916-1932

Bergeron, Y., S. Gauthier, V. Kafka, P. Lefort and D. Lesieur. 2001. Natural fire frequency for the eastern Canadian boreal forest: consequences for sustainable forestry. Can. J. For. Res. 31: 384-391.

Bergeron, Y. and B. Harvey. 1997. Basing silviculture on natural ecosystem dynamics: an approach applied to the southern boreal mixedwood forest of Quebec. For. Ecol. Manag. 92: 235-242.

Bergeron, Y., B. Harvey, A. Leduc and S. Gauthier. 1999. Forest management guidelines based on natural disturbance dynamics: Stand- and forest-level considerations. For. Chron 75: 49-54.

Bergeron, Y., A. Leduc, B. Harvey and S. Gauthier. 2002. Natural fire regime: a guide for sustainable management of the Canadian boreal forest. Silv. Fenn. 36: 81-95.

Bergeron, Y., A. Leduc, C. Joyal and H. Morin. 1995. Balsam fir mortality following the last spruce budworm outbreak in northwestern 
Quebec. Can. J. For. Res. 25: 1375-1384.

Borcard, D., P. Legendre and P. Drapeau. 1992. Partialling out the spatial component of ecological variation. Ecology. 73: 1045-1055.

Boucher, D., L. De Grandpré and S. Gauthier. 2003. Développement d'un outil de classification de la structure des peuplements et comparaison de deux territoires de la pessière à mousses du Québec. For. Chron. 79(2): 318-328.

Bull, E. and J. Jackson. 1995. Pileated Woodpecker (Dryocopus pileatus). In A. Poole (ed.). The Birds of North America Online [online]. Cornell Lab of Ornithology, Ithaca, NY. Available at http://bna.birds. cornell.edu/bna/species/148.

Carcaillet, C., Y. Bergeron, P. Richard, B. Frechette, S. Gauthier and Y. Prairie. 2001. Changes of fire frequency in the eastern Canadian boreal forest during the Holocene: does vegetation composition or climate trigger the fire regime? Ecology. 89: 930-946.

Cyr, D., S. Gauthier, Y. Bergeron and C. Carcaillet. 2009. Forest management is driving the eastern North American boreal forest outside its natural range of variability. Front. Ecol. Environ. 7: 519-524.

Dalley, K., P. Taylor and D. Shutler. 2009. Success of migratory songbirds breeding in harvest boreal forests of northwestern Newfoundland. Condor. 111: 314-325.

Darveau, M., L. Belanger, J. Huot, E. Melancon and S. Devellefeuille. 1997. Forestry practices and the risk of bird nest predation in a boreal coniferous forest. Ecol. Appl. 7: 572-580.

Deans, A.M., J.R. Malcolm, S.M. Smith and M.I. Bellocq. 2005. Edge effects and the responses of aerial insect assemblages to structural retention harvesting in Canadian boreal peatland forests. For. Ecol. Manag. 204: 249-266.

D'Eon, R.G. and W.W. Watt. 1994. A Forest Habitat Suitability Matrix for Northeastern Ontario. Natural Resources Canada, Canadian Forest Service, Timmins, ON. 83 p.

Drapeau, P., A. Leduc, Y. Bergeron, S. Gauthier and J.-P. Savard. 2003. Les communautés doiseaux des vieilles forêts de la pessière à mousses de la ceinture d’argile: Problèmes et solutions face à laménagement forestier. For. Chron. 79: 531-540.

Drapeau, P., A. Leduc, J. Giroux, J. Savard, Y. Bergeron and W. Vickery. 2000. Landscape-scale disturbances and changes in bird communities of boreal mixed-wood forests. Ecol. Mono. 70: 423-444.

Drapeau, P., A. Nappi, J-F. Giroux, A. Leduc and J-P. Savard. 2002. Distribution patterns of birds associated with snags in natural and managed boreal forests. USDA Forest Service General Technical Report PSW-GTR-181.

Drapeau, P., A. Nappi, L. Imbeau and M. Saint-Germain. 2009. Standing deadwood for keystone bird species in the eastern boreal forest: Managing for snag dynamics. For. Chron. 85: 227-234.

Ecke, F., O. Lofgren and D. Sorlin. 2002. Population dynamics of small mammals in relation to forest age and structural habitat factors in northern Sweden. J. Appl. Ecol. 39: 781-792.

Edman, M., M. Gustafsson, J. Stenlid and L. Ericson. 2004. Abundance and viability of fungal spores along a forestry gradient responses to habitat loss and isolation? Oikos 104: 35-42.

Franklin, J. 1993. Preserving biodiversity - species, ecosystems, or landscapes. Ecol. Appl. 3:202-205.

Gagné, C., L. Imbeau and P. Drapeau. 2007. Anthropogenic edges: Their influence on the American three-toed woodpecker (Picoides dorsalis) foraging behaviour in managed boreal forests of Quebec. For. Ecol. Manag. 252: 191-200.

Gauthier, S., P. Lefort, Y. Bergeron and P. Drapeau. 2002. Time since fire map, age-class distribution and forest dynamics in the Lake Abitibi Model Forest. Natural Resources Canada, Canadian Forest Service, Laurentian Forestry Centre, Information Report LAU-X-125.
Guénette, J.-S. and M.-A. Villard. 2005. Thresholds in forest bird response to habitat alterations as quantitative targets for conservation. Conserv. Biol. 19: 1168-1180.

Harvey, B., A. Leduc, S. Gauthier and Y. Bergeron. 2002. Standlandscape integration in natural disturbance-based management of the southern boreal forest. For. Ecol. Manag. 155: 369-385.

Hayden, J., J. Kerley, D. Carr, T. Kenedi and J. Hallarn. 1995. Ontario forest growth and yield program field manual for establishing and measuring permanent sample plots. Ontario Ministry of Natural Resources, Ontario Forest Research Institute, Sault Ste. Marie, ON.

Hejl, S., K. Newlon, M. Mcfadzen, J. Young and C. Ghalambor. 2002. Brown Creeper (Certhia americana). In A. Poole (ed.). The Birds of North America Online [online]. Cornell Lab of Ornithology, Ithaca, NY. Available at http://bna.birds.cornell.edu/bna/species/669.

Helle, P. and O. Jarvinen. 1986. Population trends of north Finnish land birds in relation to their habitat selection and changes in forest structure. Oikos. 46: 107-115.

Hobson, K. and E. Bayne. 2000. Breeding bird communities in boreal forest of western Canada: Consequences of "unmixing" the mixedwoods. Condor. 102: 759-769.

Hubble, S. and R. Foster. 1986. Canopy gaps and the dynamics of a Neotropical forest. In M.J. Crawley (ed.). Plant Ecology. pp. 77-95. Blackwell Scientific, Oxford, UK.

Imbeau, L., J. Savard and R. Gagnon. 1999. Comparing bird assemblages in successional black spruce stands originating from fire and logging. Can. J. Zool. 77: 1850-1860.

Jackson, S., F. Pinto, J. Malcolm and E. Wilson. 2000. A comparison of pre-settlement (1857) and current (1981-1995) forest composition in central Ontario. Can. J. For. Res. 30: 605-612.

Kneeshaw, D. and Y. Bergeron. 1996. Ecological factors affecting the abundance of advance regeneration in Quebec's southwestern boreal forest. Can. J. For. Res. 26: 888-898.

Kuttner, B., J.R. Malcolm and S.M. Smith. 2013. Multivariate classification of multi-cohort forest structure in boreal northeastern Ontario and relationships with forest age, disturbance history, and deadwood features. For. Chron. 89(3): 290-303.

Magurran, A. 1988. Ecological Diversity and its Measurement. Princeton University Press, Princeton, NJ.

Malcolm, J. 1994. Edge effects in central Amazonian forest fragments. Ecology. 75: 2438-2445.

McRae, D., L. Duchesne, B. Freedman, T. Lynham and S. Woodley. 2001. Comparisons between wildfire and forest harvesting and their implications in forest management. Environ. Rev. 9: 223-260.

Nguyen, T. 2000. Classification of Northern Abitibi's spruce-moss forest stands according to their internal structure. Preliminary report to the Quebec Ministry of Natural Resources. July 2000. 24 p.

[OMNR] Ontario Ministry of Natural Resources. 2001. Forest management guide for natural disturbance pattern emulation, Version 3.1. Queen's Printer for Ontario, Toronto, ON.

Philips, J., E. Nol, D. Burke and W. Dunford. 2005. Impacts of housing developments on Wood Thrush nesting success in hardwood forest fragments. Condor. 107: 97-106.

Poole, A.( ed.). 2009. The Birds of North America Online [online]. Cornell Lab of Ornithology, Ithaca, NY. Available at http://bna.birds. cornell.edu/bna.

Remmel, T., K. Todd and J. Buttle. 2008. A comparison of existing surficial hydrological data layers in a low-relief forested Ontario landscape with those derived from a LiDAR DEM. For. Chron. 84: 850-865. Rowe, J.S. 1972. Forest Regions of Canada. Rev. edition. Dept. of the Environment. Canadian Forestry Service. Publication, no. 1300 Information Canada, Ottawa, ON. 172 p.

Savignac, C. and C. Machtans. 2006. Habitat requirements of the Yellow-bellied Sapsucker, Sphyrapicus varius, in boreal mixedwood forests of northwestern Canada. Can. J. Zoolog. 84: 1230-1239. 
Taylor, K., R. Arnup, B. Merchant, W. Parton and J. Nieppola. 2000. A Field Guide to Forest Ecosystems of Northeastern Ontario, 2nd Edition. Ontario Ministry of Natural Resources, Queen's Printer for Ontario, Toronto, ON.
Thompson, I., D. Ortiz, C. Jastrebski and D. Corbett 2006. A comparison of prism plots and modified point-distance sampling to calculate tree stem density and basal area. North. J. Appl. For. 23: 218-221.

Van Horne, B. 1983. Density as a misleading indicator of habitat quality. J. Wild. Manag. 47: 893-901.

Appendix 1. Locations and characteristics of 45 boreal mixedwood sites in northeastern Ontario sampled for habitat features and bird communities.

\begin{tabular}{lccccc}
\hline & & & Cohort & FEC & Stand \\
Site code & Longitude & Latitude & class & site type & age $^{\mathrm{b}}$ \\
\hline CHT-050-16 & -82.1471 & 48.18138 & 2 & $7 \mathrm{~b}$ & 81 \\
CHT-050-17 & -82.1572 & 48.16937 & 4 & $7 \mathrm{~b}$ & 91 \\
Mike002 & -82.1201 & 48.04886 & 2 & $6 \mathrm{~b}$ & 71 \\
Mike007 & -81.9068 & 48.22022 & 2 & $7 \mathrm{~b}$ & 76 \\
Mike009 & -81.6659 & 48.34895 & 2 & $7 \mathrm{~b}$ & 85 \\
Mike012 & -81.7331 & 48.57046 & 2 & $5 \mathrm{~b}$ & 57 \\
Mike013 & -81.7438 & 48.52301 & 1 & $7 \mathrm{~b}$ & 33 \\
Mike019 & -81.9624 & 48.23104 & 2 & $9 \mathrm{~b}$ & 60 \\
Mike021 & -81.5614 & 48.45211 & 3 & $7 \mathrm{~b}$ & 70 \\
Mike023 & -81.7582 & 48.39469 & 2 & $7 \mathrm{~b}$ & 69 \\
Mike024 & -81.7477 & 48.37589 & 4 & $7 \mathrm{~b}$ & 75 \\
NW001 & -81.8315 & 48.21043 & 2 & $6 \mathrm{~b}$ & 61 \\
NW002 & -81.7938 & 48.25068 & 1 & $7 \mathrm{~b}$ & 61 \\
NW003 & -81.7875 & 48.48702 & 2 & $7 \mathrm{~b}$ & 94 \\
NW004 & -81.8803 & 48.53966 & 1 & $7 \mathrm{~b}$ & 55 \\
NW013 & -81.4225 & 48.4363 & 2 & $6 \mathrm{~b}$ & 81 \\
NW016 & -81.4462 & 48.00405 & 1 & $6 \mathrm{a}$ & 38 \\
NW017 & -81.6557 & 48.00947 & 1 & $6 \mathrm{~b}$ & 40 \\
NW018 & -81.9289 & 48.55706 & 1 & $7 \mathrm{~b}$ & 35 \\
NW022 & -81.8095 & 48.50779 & 1 & $7 \mathrm{~b}$ & 91 \\
NW025 & -81.8038 & 48.49307 & 1 & $7 \mathrm{~b}$ & 77 \\
NW026 & -82.2626 & 48.10795 & 1 & $6 \mathrm{c}$ & 106 \\
NW027 & -82.2546 & 48.14974 & 3 & $6 \mathrm{~b}$ & 67 \\
\hline & & & & &
\end{tabular}

\begin{tabular}{lccccc}
\hline Site code & Longitude & Latitude & $\begin{array}{c}\text { Cohort } \\
\text { class }\end{array}$ & $\begin{array}{c}\text { FEC } \\
\text { site type }\end{array}$ & $\begin{array}{c}\text { Stand } \\
\text { age }^{\mathrm{b}}\end{array}$ \\
\hline NW028 & -81.7178 & 48.61818 & 2 & $5 \mathrm{~b}$ & 54 \\
Tem-01-015 & -81.9345 & 48.23925 & 2 & $3 \mathrm{~b}$ & 56 \\
Tem-01-022 & -81.9627 & 48.2227 & 4 & $9 \mathrm{~b}$ & 76 \\
Tem-01-023 & -81.9589 & 48.18551 & 1 & $7 \mathrm{~b}$ & 29 \\
Tem-01-025 & -81.9692 & 48.17909 & 1 & $7 \mathrm{~b}$ & 25 \\
Tem-01-028 & -82.0268 & 48.0037 & 3 & $7 \mathrm{~b}$ & 86 \\
Tem-01-035 & -81.7157 & 48.594 & 4 & $5 \mathrm{~b}$ & 107 \\
Tem-01-038 & -81.8588 & 48.21771 & 4 & $6 \mathrm{c}$ & 96 \\
Tem-01-040 & -81.978 & 48.23038 & 1 & $5 \mathrm{a}$ & 34 \\
Tem-01-042 & -81.9088 & 48.20173 & 1 & $6 \mathrm{~b}$ & 51 \\
Tem-02-041 & -81.6604 & 48.30795 & 2 & $7 \mathrm{~b}$ & 90 \\
Tem-02-051 & -81.9455 & 48.56867 & 1 & $7 \mathrm{~b}$ & 37 \\
Tem-02-062 & -82.0918 & 48.12962 & 4 & $3 \mathrm{a}$ & 53 \\
Tem-03-043 & -82.2472 & 48.18463 & 4 & $5 \mathrm{~b}$ & 147 \\
Tem-03-045 & -81.8434 & 48.23916 & 3 & $7 \mathrm{~b}$ & 71 \\
Tem-03-047 & -81.8092 & 48.25933 & 2 & $7 \mathrm{~b}$ & 61 \\
Tem-03-048 & -81.793 & 48.2811 & 1 & $7 \mathrm{~b}$ & 81 \\
Tem-03-049 & -81.729 & 48.3286 & 2 & $7 \mathrm{~b}$ & 90 \\
Tem-03-065 & -81.744 & 48.2464 & 1 & $5 \mathrm{~b}$ & 56 \\
Tem-03-079 & -81.53 & 48.0006 & 4 & $7 \mathrm{~b}$ & 61 \\
Tem-03-080 & -81.53 & 47.9687 & 4 & $9 \mathrm{~b}$ & 56 \\
Tim9341 & -81.762 & 48.4102 & 1 & $7 \mathrm{~b}$ & 55 \\
\hline & & & & & \\
\hline
\end{tabular}

${ }^{\text {a }}$ Forest Ecosystem Classification (Taylor et al. 2000).

${ }^{\mathrm{b}}$ Stand age was from the digital Forest Resource Inventory (Ontario Ministry of Natural Resources, unpubl.). 
Appendix 2. Structural habitat features sampled in 45 boreal mixedwood stands in northeastern Ontario.

\begin{tabular}{ll}
\hline Variable code & Description \\
\hline CAN_HT & Mean canopy height \\
CAN_HT_V & Variance of canopy height (with mean partialled out) \\
CAN_HT_S & Semivariance of canopy height (with mean partialled out) \\
U_THK & Mean thickness of understorey layer (0-10 m) \\
U_THK_V & Variance of understorey thickness (with mean partialled out) \\
U_THK_S & Semivariance of understorey thickness (with mean partialled out) \\
M_THK & Mean thickness of lower canopy (10-15 m) \\
M_THK_V & Variance of lower canopy thickness (with mean partialled out) \\
M_THK_S & Semivariance of lower canopy thickness (with mean partialled out) \\
C_THK & Mean thickness of upper canopy (15-35 m) \\
C_THK_V & Variance of upper canopy thickness (with mean partialled out) \\
C_THK_S & Semivariance of upper canopy thickness (with mean partialled out) \\
FHD & Foliage height diversity \\
CC_RICH & Canopy class richness (residual) \\
CC_DIV & Canopy class diversity \\
LV_BA & Basal area of live stems (>2.5 cm DBH) per ha \\
SNG_BA & Basal area of snags per ha \\
CWD_13 & Early decay class (1-3) coarse woody debris (cm/m) \\
CWD_45 & Late decay class (4-5) coarse woody debris (cm/m) \\
SHRB_STM & Shrub stems per ha \\
PCT_DECID & Percentage of live basal area composed of deciduous trees \\
\hline
\end{tabular}

Appendix 3. Bird species detected on point counts and playback surveys and their incidence and relative abundance in boreal mixedwood forests in northeastern Ontario (sorted by number of sites present).

\begin{tabular}{|c|c|c|c|c|c|c|}
\hline $\begin{array}{l}\text { Species } \\
\text { code }\end{array}$ & Common name & Scientific name & $\begin{array}{l}\text { Feeding } \\
\text { guild }^{\mathrm{a}}\end{array}$ & $\begin{array}{l}\text { Forest-type } \\
\text { guild }^{\mathrm{a}}\end{array}$ & $\begin{array}{l}\text { Number of } \\
\text { sites present }\end{array}$ & $\begin{array}{c}\text { Relative } \\
\text { abundance }^{b}\end{array}$ \\
\hline RBNU & Red-breasted Nuthatch & Sitta canadensis & Bark & Coniferous & 43 & 1.78 \\
\hline REVI & Red-eyed Vireo & Vireo olivaceus & Canopy & Deciduous & 43 & 2.29 \\
\hline OVEN & Ovenbird & Seiurus aurocapilla & Ground & Deciduous & 40 & 1.36 \\
\hline MAWA & Magnolia Warbler & Setophaga magnolia & Shrub & Coniferous & 35 & 1.11 \\
\hline YBSA & Yellow-bellied Sapsucker & Sphyrapicus varius & Bark & Deciduous & 32 & 1.09 \\
\hline HETH & Hermit Thrush & Catharus guttatus & Ground & Coniferous & 27 & 0.73 \\
\hline MYWA & Yellow-rumped Warbler & Setophaga coronata & Shrub & Coniferous & 27 & 0.76 \\
\hline SWTH & Swainson's Thrush & Catharus ustulatus & Ground & Coniferous & 27 & 0.67 \\
\hline GCKI & Golden-crowned Kinglet & Regulus satrapa & Canopy & Coniferous & 26 & 0.73 \\
\hline BLBW & Blackburnian Warbler & Setophaga fusca & Canopy & Deciduous & 25 & 0.69 \\
\hline PISI & Pine Siskin & Spinus pinus & Seed & Coniferous & 24 & 0.73 \\
\hline $\mathrm{BCCH}$ & Black-capped Chickadee & Poecile atricapillus & Generalist & Mixedwood & 23 & 1.02 \\
\hline WIWR & Winter Wren & Troglodytes hiemalis & Shrub & Mixedwood & 23 & 0.53 \\
\hline WTSP & White-throated Sparrow & Zonotrichia albicollis & Ground & Coniferous & 22 & 0.58 \\
\hline NAWA & Nashville Warbler & Oreothlypis ruficapilla & Shrub & Coniferous & 21 & 0.6 \\
\hline BBWA & Bay-breasted Warbler & Setophaga castanea & Canopy & Coniferous & 20 & 0.51 \\
\hline DOWO & Downy Woodpecker & Picoides pubescens & Bark & Deciduous & 19 & 0.47 \\
\hline
\end{tabular}


Appendix 3. Bird species detected on point counts and playback surveys and their incidence and relative abundance in boreal mixedwood forests in northeastern Ontario (sorted by number of sites present). (continued)

\begin{tabular}{|c|c|c|c|c|c|c|}
\hline $\begin{array}{l}\text { Species } \\
\text { code }\end{array}$ & Common name & Scientific name & $\begin{array}{l}\text { Feeding } \\
\text { guild }^{\mathrm{a}}\end{array}$ & $\begin{array}{l}\text { Forest-type } \\
\text { guild }^{\mathrm{a}}\end{array}$ & $\begin{array}{l}\text { Number of } \\
\text { sites present }\end{array}$ & $\begin{array}{c}\text { Relative } \\
\text { abundance }^{\mathrm{b}}\end{array}$ \\
\hline NOPA & Northern Parula & Setophaga americana & Canopy & Mixedwood & 18 & 0.4 \\
\hline BTBW & Black-throated Blue Warbler & Setophaga caerulescens & Shrub & Deciduous & 16 & 0.4 \\
\hline AMRO & American Robin & Turdus migratorius & Ground & Mixedwood & 14 & 0.36 \\
\hline PUFI & Purple Finch & Carpodacus purpureus & Seed & Coniferous & 14 & 0.31 \\
\hline WWCR & White-winged Crossbill & Loxia leucoptera & Seed & Coniferous & 12 & 0.4 \\
\hline BHVI & Blue-headed Vireo & Vireo solitarius & Canopy & Coniferous & 10 & 0.24 \\
\hline RCKI & Ruby-crowned Kinglet & Regulus calendula & Canopy & Coniferous & 10 & 0.24 \\
\hline BLJA & Blue Jay & Cyanocitta cristata & Generalist & Mixedwood & 8 & 0.2 \\
\hline $\mathrm{BOCH}$ & Boreal Chickadee & Poecile hudsonica & Shrub & Coniferous & 8 & 0.29 \\
\hline CEDW & Cedar Waxwing & Bombycilla cedrorum & Generalist & Mixedwood & 8 & 0.18 \\
\hline YBFL & Yellow-bellied Flycatcher & Empidonax flaviventris & Shrub & Coniferous & 7 & 0.18 \\
\hline BAWW & Black-and-white Warbler & Mniotilta varia & Bark & Mixedwood & 6 & 0.13 \\
\hline BTNW & $\begin{array}{l}\text { Black-throated Green } \\
\text { Warbler }\end{array}$ & Setophaga virens & Canopy & Coniferous & 6 & 0.13 \\
\hline BRCR & Brown Creeper & Certhia americana & Bark & Mixedwood & 5 & 0.11 \\
\hline GRJA & Gray Jay & Perisoreus canadensis & Generalist & Coniferous & 5 & 0.16 \\
\hline VEER & Veery & Catharus fuscescens & Ground & Deciduous & 5 & 0.13 \\
\hline LEFL & Least Flycatcher & Empidonax minimus & Shrub & Deciduous & 4 & 0.13 \\
\hline NOFL & Northern Flicker & Colaptes auratus & Ground & Mixedwood & 4 & 0.11 \\
\hline AMRE & American Redstart & Setophaga ruticilla & Shrub & Deciduous & 3 & 0.07 \\
\hline CORA & Common Raven & Corvus corax & Generalist & Mixedwood & 3 & 0.07 \\
\hline SCTA & Scarlet Tanager & Piranga olivacea & Canopy & Deciduous & 3 & 0.07 \\
\hline AMGO & American Goldfinch & Spinus tristis & Seed & Mixedwood & 2 & 0.04 \\
\hline $\mathrm{BBCU}$ & Black-billed Cuckoo & $\begin{array}{l}\text { Coccyzus } \\
\text { erythropthalmus }\end{array}$ & Canopy & Deciduous & 2 & 0.04 \\
\hline CSWA & Chestnut-sided Warbler & Setophaga pennsylvanica & Shrub & Deciduous & 2 & 0.04 \\
\hline HAWO & Hairy Woodpecker & Picoides villosus & Bark & Mixedwood & 2 & 0.04 \\
\hline MOWA & Mourning Warbler & Geothlypis philadelphia & Shrub & Deciduous & 2 & 0.07 \\
\hline PHVI & Philadelphia Vireo & Vireo philadelphicus & Canopy & Mixedwood & 2 & 0.04 \\
\hline PIWO & Pileated Woodpecker & Dryocopus pileatus & Bark & Mixedwood & 2 & 0.04 \\
\hline RECR & Red Crossbill & Loxia curvirostra & Seed & Coniferous & 2 & 0.04 \\
\hline TEWA & Tennessee Warbler & Oreothlypis peregrina & Canopy & Coniferous & 2 & 0.04 \\
\hline WIWA & Wilson's Warbler & Cardellina pusilla & Shrub & Mixedwood & 2 & 0.04 \\
\hline CAWA & Canada Warbler & Cardellina canadensis & Shrub & Mixedwood & 1 & 0.02 \\
\hline CMWA & Cape May Warbler & Setophaga tigrina & Canopy & Coniferous & 1 & 0.02 \\
\hline DEJU & Dark-eyed Junco & Junco hyemalis & Ground & Coniferous & 1 & 0.02 \\
\hline RUBL & Rusty Blackbird & Euphagus carolinus & Ground & Coniferous & 1 & 0.02 \\
\hline WPWA & Palm Warbler & Setophaga palmarum & Shrub & Coniferous & 1 & 0.02 \\
\hline
\end{tabular}

${ }^{a}$ Feeding and habitat guilds were based on information in Poole (2009; see Table 1)

${ }^{\mathrm{b}}$ Abundance at a site was measured as the maximum number of individuals detected on any of the six five-minute point counts or during playback sampling (see text for details). 